\title{
Monoclonal Antibody A1G4 Anti-Idiotype Vaccine
}

National Cancer Institute

\section{Source}

National Cancer Institute. Monoclonal Antibody A1G4 Anti-ldiotype Vaccine. NCI

Thesaurus. Code C2436.

An anti-idiotypic (anti-Id) rat monoclonal antibody (MoAb) that mimics the

disialog ang lioside GD2, a cancer-associated antigen present on melanoma, small cell lung cancer, sarcoma, neuroblastoma, and other malignancies. GD2 is a highly expressed glycosphing olipid by melanoma and other neuroectodermal tumors with only minimal expression on normal tissues. Vaccination with anti-Id A1G4 MoAb may elicit cellular and humoral immune responses against GD2 expression tumor cells. 